\title{
RNA Associated with a Heterodimeric Protein that Activates a Meiotic Homologous Recombination Hot Spot: RL/RT/PCR Strategy for Cloning any Unknown RNA or DNA
}

\author{
Wayne P. Wahls
}

Fred Hutchinson Cancer Research Center, Seattle, Washington 98104

\begin{abstract}
The ade6-M26 mutation in the fission yeast Schizosaccharomyces pombe creates a melotic homologous recombination hot spot. We have achieved 40,000 -fold purification of a heterodimeric DNA-binding protein, Mts1/Mts2, that activates the recombination hot spot. Physical studies suggested the presence of a third subunit. It is demonstrated here that RNA molecules of $\sim 210$ nucleotides copurified with the heterodimer. To characterize the RNA component, it was necessary to develop a new strategy for cloning of the unknown, lowabundance, partially degraded RNAs that were present in purified Mts1/ Mts2 protein preparations. The strategy uses RNA ligase to add DNA oligonucleotide priming sites to the RNA for subsequent reverse transcription and PCR (RNA ligase, reverse transcription-PCR, or RL/RT/PCR). This cloning procedure could be applied to the cloning of any unknown RNA or DNA molecules. Because the CDNA clones obtained from Mts1/Mts2 were largely heterogeneous, it seems likely that the RNAs copurified as a result of tight but nonspecific interactions with the heterodimeric protein.
\end{abstract}

$\mathbf{H}$ omologous recombination hot spots are DNA elements that increase the frequency of recombination events in their vicinity. Because recombination hot spots must promote rate-limiting steps in recombination pathways, we can gain a better understanding of the mechanisms of recombination if we can elucidate how recombination hot spots function.

The M26 allele of the ade6 gene in Schizosaccharomyces pombe is in many ways the best understood eukaryotic recombination hot spot (for review, see ref. 1). Based on his genetic data, Gutz proposed that the $M 26$ mutation created a recognition site for a recombinationpromoting protein. ${ }^{(2)}$ Consistent with this hypothesis is the finding that a specific heptanucleotide sequence, 5'-ATGACGT-3' (M26 mutation underlined), is required for hot spot activity in vivo. ${ }^{(3)}$ We have recently achieved 40,000-fold purification of a heterodimeric protein, composed of polypeptides Mts1 (70 kD) and Mts2 (28 kD), that binds to the heptanucleotide M26 site, and we have demonstrated that protein binding is required for homologous recombination hot spot activity. ${ }^{(4)}$

Although the Mts1/Mts2 heterodimer was necessary and sufficient to confer recombination hot spot binding activity, physical studies suggested the presence of a third subunit. ${ }^{(4)}$ Mobility retardation assays with purified protein revealed two M26-specific protein-DNA complexes. A heterodimer of Mts1 and Mts2 was required for the formation of each of the complexes. However, when Mts 1 and Mts 2 were isolated and mixed, only one of the complexes was restored. Thus, some third factor (presumably interacting with the Mts1/Mts2 heterodimer) must have been required for the second protein-DNA complex. However, we were unable to identify a good polypeptide candidate for that third subunit. Because RNA subunits have been detected in other enzymes involved in nucleic acid metabolism, ${ }^{(5-9)}$ including one required for some biochemical activities of the Escherichia coli RecBCD enzyme that activates the $\chi$ recombination hot spot, ${ }^{(10)}$ we reasoned that the putative third subunit of the recombination hot spot activating enzyme might be composed of RNA.

It is demonstrated here that RNA molecules of $\sim 210$ nucleotides in length copurified with the recombination hot spot binding protein. Also described is the PCR-based strategy that was developed to clone the unknown, low-abundance, partially degraded RNA that was present in the Mts1/Mts2 protein preparation. This procedure can be applied to the cloning of any unknown RNA or DNA molecules.

\section{MATERIALS AND METHODS Mts1/Mts2 Protein}

Purification of the Mts1/Mts2 heterodimer is described elsewhere. ${ }^{(4)}$ Fraction VI was purified 40,000-fold and contained $>50 \% \mathrm{Mts} 1 / \mathrm{Mts} 2$ heterodimer by weight as judged by SDS-page analy- 
ses $^{(11)}$ (see Fig. 3A, below). Protein was concentrated by TCA precipitation and resuspended in SDS-page loading buffer. ${ }^{(12)}$

\section{Preparation of RNA}

Fifteen microliters of fraction VI containing $\sim 1 \mu \mathrm{g}$ of total protein was diluted to $200 \mu \mathrm{l}$ in $\mathrm{TE}$, extracted serially with equal volumes of phenol, phenol/ chloroform, and chloroform, and precipitated with ethanol. The pellet was dried briefly and resuspended in $18 \mu$ of $1 \times$ phosphatase buffer (Boehringer Mannheim) containing 2 units of RNase Block II (Strategene). Two microliters of calf intestinal phosphatase ( 2 units; Boehringer Mannheim) was added, the reaction was incubated at $45^{\circ} \mathrm{C}$ for $30 \mathrm{~min}$ and adjusted to $25 \mathrm{mM}$ EGTA with $2.2 \mu \mathrm{l}$ of $250 \mathrm{~mm}$ stock, and the enzyme was heat-inactivated at $65^{\circ} \mathrm{C}$ for $30 \mathrm{~min}$. To this reaction were added $6.8 \mu \mathrm{l}$ of $\mathrm{H}_{2} \mathrm{O}, 4$ $\mu \mathrm{l}$ of $10 \times$ kinase buffer, ${ }^{(12)} 2 \mu$ l of RNase Block II ( 2 units), $4 \mu$ l of $\left[\gamma_{-}{ }^{32}\right.$ P]ATP (New England Nuclear; $3000 \mathrm{Ci} / \mathrm{mmole}$ ), and 1 $\mu \mathrm{l}$ of T4 polynucleotide kinase (20 units; New England Biolabs). After incubation at $37^{\circ} \mathrm{C}$ for $60 \mathrm{~min}$, the enzyme was heatinactivated at $65^{\circ} \mathrm{C}$ for $15 \mathrm{~min}$, the mixture was extracted with phenol, phenol/ chloroform, and chloroform, and the RNA was precipitated with ethanol. The pellet was dried briefly and resuspended in $50 \mu \mathrm{l}$ of TE containing 2 units of RNase Block II. The labeled RNA was fractionated on a $7 \mathrm{M}$ urea, $6 \%$ polyacrylamide gel and visualized by autoradiography, and the 210-nucleotide RNA band was excised. The gel slice was diced and incubated at $21^{\circ} \mathrm{C}$ with agitation for 16 $\mathrm{hr}$ in $500 \mu \mathrm{l}$ of TE containing 5 units of RNase Block II. The eluted material was precipitated with ethanol, the pellet was dried briefly, and the amount of incorporated label was determined in a scintillation counter. The total number of RNA molecules present was calculated from the Cerenkov value, the counting efficiency, and the specific activity of the label $(100 \%$ labeling efficiency was observed with control RNA fragments using this protocol; data not shown).

\section{Addition of Linkers}

Phosphorylated BamHI linker DNA (5'CGCGGATCCGCG-3') was obtained from New England Biolabs. An aliquot was labeled with $\left[\gamma^{32}\right.$ P]ATP using poly- nucleotide kinase under the manufacturer's conditions for the exchange reaction (New England Biolabs). Labeled and unlabeled linkers were mixed to achieve the desired specific activity. Linkers were boiled and quenched on ice immediately before adding them to reactions to ensure the presence of single-stranded linkers.

Two identical reactions, differing only by the presence or absence of RNA, were set up. Approximately 10 fmoles of labeled RNA $(15,000 \mathrm{cpm}$ total) was resuspended in $18 \mu \mathrm{l}$ of $1 \times$ RNA ligase buffer (50 mM Tris- $\mathrm{HCl}$ at $\mathrm{pH} 7.8,10 \mathrm{~mm}$ $\mathrm{MgCl}_{2}, 10 \mathrm{~mm} \beta$-mercaptoethanol, 10 mM ATP) containing 1 unit of RNase Block II. One microliter of linkers ( 500 fmoles, $15,000 \mathrm{cpm}$ total) and $1 \mu \mathrm{l}$ of RNA ligase (20 units; New England Biolabs) were added, and the reactions were incubated at $37^{\circ} \mathrm{C}$ for $2 \mathrm{hr}$ and heat inactivated at $65^{\circ} \mathrm{C}$ for $15 \mathrm{~min}$. Ten percent of each reaction was fractionated on a 7 $\mathrm{M}$ urea, $6 \%$ polyacrylamide gel and visualized by autoradiography.

\section{Reverse Transcription}

A single buffer was used for both reverse transcription and PCR $(10 \times$ RT-PCR buffer: $200 \mathrm{~mm}$ Tris- $\mathrm{HCl}$ at $\mathrm{pH} 8.4,500$ $\mathrm{mM} \mathrm{KCl}, 25 \mathrm{~mm} \mathrm{MgCl}_{2}, 1 \mathrm{mg} / \mathrm{ml}$ of BSA fraction V; Sigma). Eighteen microliters of ligation reaction, $9 \mu \mathrm{l}$ of $\mathrm{H}_{2} \mathrm{O}, 5 \mu \mathrm{l}$ of $10 \times$ RT-PCR buffer, $5 \mu$ l of RNase Block II, $10 \mu$ l of $5 \mathrm{~mm} 4 \mathrm{dNTPs}$ (to $1 \mathrm{~mm}$ each), $1 \mu$ l of additional BamHI linkers (250 pmoles, $100,000 \mathrm{cpm}$ ), and $1 \mu \mathrm{l}$ of Moloney murine leukemia virus (Mo-MLV) reverse transcriptase (200 units; Bethesda Research Laboratories) were mixed. The reactions were incubated at $22^{\circ} \mathrm{C}$ for $15 \mathrm{~min}, 37^{\circ} \mathrm{C}$ for $15 \mathrm{~min}$, and $65^{\circ} \mathrm{C}$ for $15 \mathrm{~min}$. The reverse transcription products were immediately used for PCR.

\section{PCR Reactions}

One hundred and forty-nine microliters of $1 \times$ RT-PCR buffer was added to the heat-inactivated ligation reactions to dilute the dNTP concentration to $250 \mu \mathrm{M}$ to reduce the misincorporation rate of Taq polymerase. One microliter of Taq polymerase (5 units; Boehringer Mannheim) was added, and 35 amplification cycles $\left(95^{\circ} \mathrm{C}\right.$ for $30 \mathrm{sec}, 37^{\circ} \mathrm{C}$ for $60 \mathrm{sec}$, $72^{\circ} \mathrm{C}$ for $30 \mathrm{sec}$ ) were conducted. The final $72^{\circ} \mathrm{C}$ extension was for $15 \mathrm{~min}$ to en- sure maximum full-length product formation. The PCR products were extracted serially with phenol, phenol/ chloroform, and chloroform and precipitated with ethanol, and the pellets were resuspended in $50 \mu \mathrm{l}$ of TE. Half of each PCR reaction was digested with Bam $\mathrm{HI}$. PCR products were analyzed on an ethidium bromide-stained 3\% agarose gel ( $20 \%$ of each PCR product per lane) and by autoradiography of samples run on a native $6 \%$ acrylamide gel ( $5 \%$ of each PCR product per lane).

\section{Cloning and Sequencing PCR Products}

BamHI-digested PCR product was fractionated on a $1 \%$ agarose gel, and the band was excised, electroeluted in TBE, and recovered by precipitation with ethanol. The cDNAs were cloned into the dephosphorylated BamHI site of pBluescript II $\mathrm{KS}(+)$ (Stratagene) using conventional techniques ${ }^{(13)}$ and introduced into $E$. coli strain $\mathrm{DH} 5 \alpha$. Transformants with inactivated $\beta$-galactosidase function were chosen for analysis. Plasmid miniprep DNA was made by the polyethylene glycol precipitation, alkaline lysis method (Applied Biosystems booklet 901497). Both strands of each clone were sequenced, from the T3 and T7 priming sites, respectively, using the Dye-Deoxy dsDNA sequencing method (Applied Biosystems). Sequences were analyzed for homology with each other by using Genetics Computer Group software ${ }^{(14)}$ and for homology with known sequences by using the Blast Network Server.

\section{RESULTS}

\section{Identification of RNA Molecules}

To investigate the possibility of a nucleic acid subunit of the Mts1/Mts2 protein, the purest fractions were deproteinized by phenol/chloroform extraction. The resulting material was precipitated with ethanol, treated with phosphatase, labeled with $\left[\gamma^{32} \mathrm{P}\right]$ ATP using polynucleotide kinase, and run on a $6 \%$ urea-polyacrylamide sequencing gel. A single discrete band of $\sim 210$ nucleotides and a heterogeneous smear trailing down to oligonucleotide size were observed (Fig. 1). All of the labeled material was resistant to DNase I and proteinase $\mathrm{K}$ treatment, sensitive to alkaline hydrolysis, 


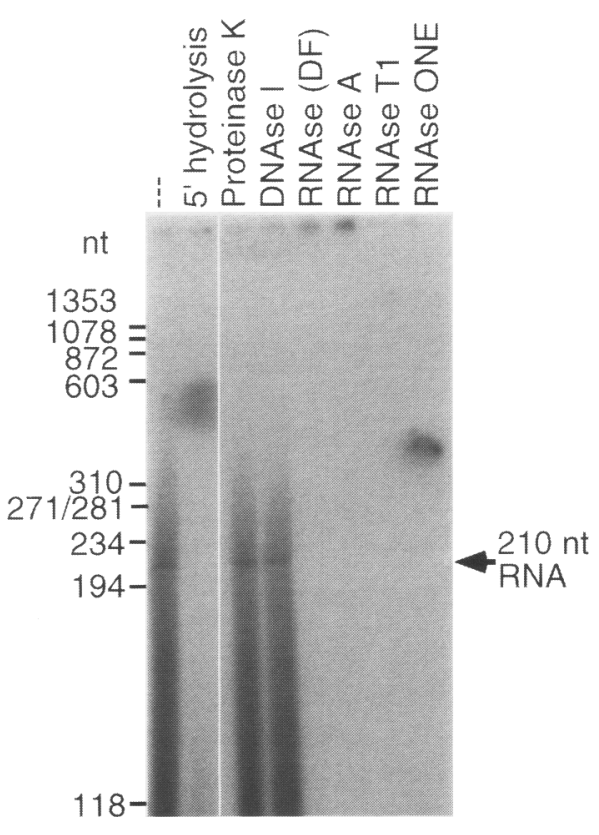

FIGURE 1 Identification of 210-nucleotide RNA molecule. Autoradiograph of material extracted from purified Mts1/Mts2 protein, labeled with $\left[\gamma_{-}{ }^{32} \mathrm{P}\right] \mathrm{ATP}$ using polynucleotide kinase, and run on a $6 \%$ polyacrylamide ureapolyacrylamide sequencing gel. Samples were treated as indicated. (DF) DNase-free. Markers were as in Fig. 3C.

and sensitive to a variety of RNase enzymes (Fig. 1). Thus, RNA molecules of $\sim 210$ nucleotides in length copurified with the Mts1/Mts2 protein.

\section{Cloning the RNA}

Several challenges were faced in cloning the 210-nucleotide RNA. Perhaps most significant, the sequence and polyadenylation state were unknown. Furthermore, the 210-nucleotide RNA was either highly degraded or contaminated with heterogeneous RNAs (Fig. 1). Finally, because the RNA was isolated from highly purified (40,000-fold), low-abundance protein, there was a severely limited amount of material to work with.

A cloning strategy (Fig. 2) was devised to fulfill several requirements. First, the strategy involved the ability to clone any very low-abundance RNA without any knowledge of its primary sequence. Second, it was desirable to minimize the expense, to use materials generally available in molecular biology laboratories, and to avoid complicated strategies that relied on sequential manipulations with multiple oligonucleotide linkers and primers. Therefore, a single, self-complementary palindromic, 12-nucleotide BamHI linker was used to provide both priming sites, to prime for cDNA synthesis, and to prime for PCR amplification.

SDS-PAGE analysis revealed that the Mts1/Mts2 heterodimer was highly purified (Fig. 3A). RNA extracted from protein was dephosphorylated, phosphorylated with $\left[\gamma^{-32} \mathrm{P}\right] \mathrm{ATP}$, and fractionated on a $6 \%$ urea-PAGE gel. The material present in a discrete band (Fig. 3B) was eluted in TE containing RNase inhibitors. From the specific activity of $\left[\gamma^{-32}\right.$ P]ATP, a recovery of $\sim 10$ fmoles of gel-purified RNA was calculated.

Two separate ligation reactions were set up, one containing phosphorylated BamHI linkers alone as a control, and the other containing BamHI linkers and RNA (50:1 molar ratio). The linkers were boiled briefly and quenched on ice prior to addition to ensure the presence of single-stranded DNA (ssDNA). Both the RNA and the BamHI linkers were par- tially radioactively labeled at their $5^{\prime}$ phosphates, each to $\sim 15,000 \mathrm{cpm}$ per reaction, to allow visualization of the reaction products. RNA ligase, which will ligate any ssDNA and RNA molecules with 5 '-phosphate and 3'-hydroxyl groups, was used to ligate the BamHI linkers onto both ends of the RNA. Ten percent of each reaction was analyzed on a $6 \%$ urea-polyacrylamide gel (Fig. 3C).

Because both the RNA and the linkers were 5 '-end-labeled, the gel analysis was quite informative. First, the reaction with linkers alone gave no significant products longer than 60 nucleotides in length (Fig. 3C, lane 2). Thus, the linker concentration and ligation conditions were appropriate to prevent the formation of long concatemers of linkers. Second, it was evident that the gel-purified RNA suffered further degradation during the ligation reaction, presumably as a result of its low abundance and the presence of a small amount of contaminating RNase activity in the RNA ligase

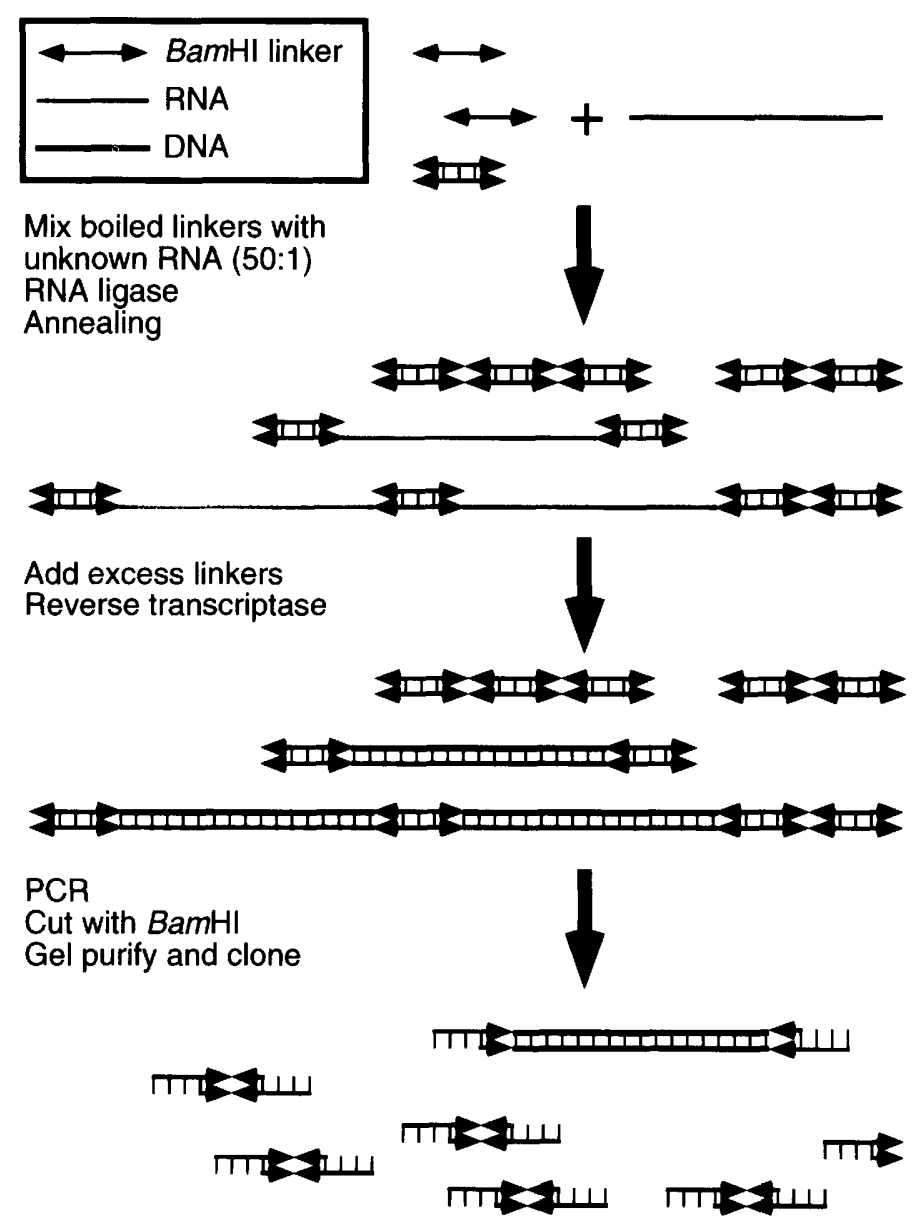

FICURE 2 Strategy for cloning unknown RNA (or DNA) molecules. Details are provided in the text. 


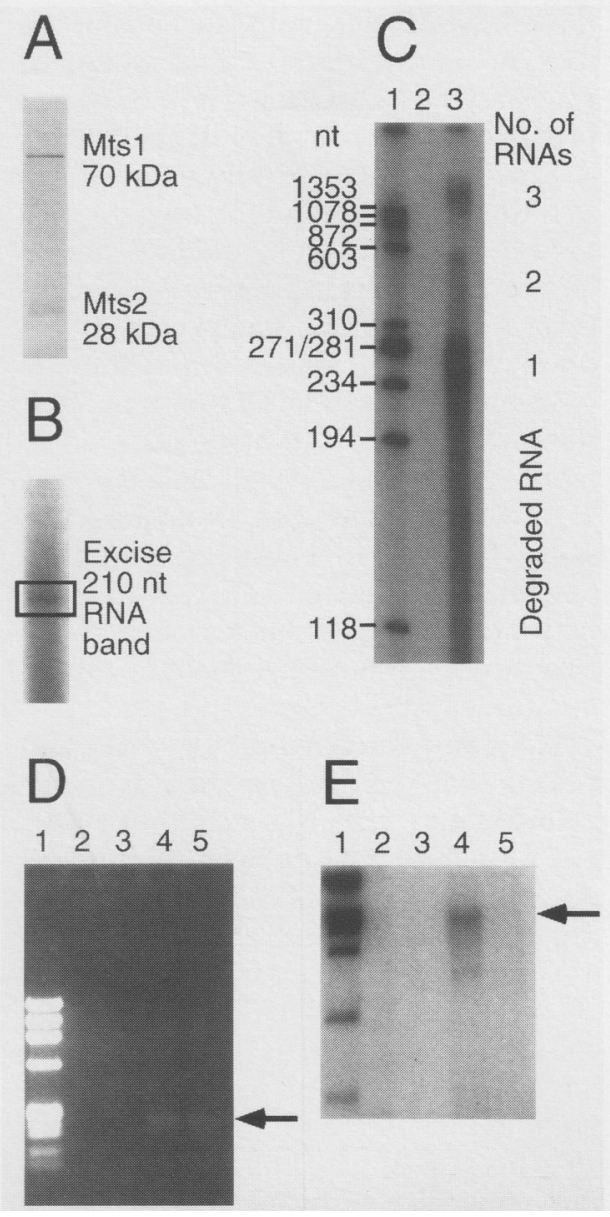

FIGURE 3 Analysis of substrates, intermediates, and products. (A) Coomassie-stained, $12 \%$ polyacrylamide SDS-polyacrylamide gel analysis of purified Mts1/Mts2 heterodimer protein. (B) Autoradiograph of labeled RNA obtained from Mts1/Mts2 protein fractionated on a $6 \%$ urea-polyacrylamide gel. The 210-nucleotide band was excised as indicated. (C) Autoradiograph of ligation products analyzed on $6 \%$ urea-polyacrylamide gel. (Lane 1) Boiled $\phi X 174$ HaeIII markers; (lane 2) linker reaction; (lane 3 ) linker plus RNA reaction. The linkers and RNA were radioactively labeled to an equivalent level. $(D)$ Ethidium bromide-stained, $3 \%$ agarose gel of PCR reaction products. (Lane 1) $\phi X 174$ HaelII markers; (lane 2) linker reaction; (lane 3) linker reaction digested with BamHI; (lane 4) linker plus RNA reaction; (lane 5) linker plus RNA reaction digested with BamHI. Arrow indicates position of PCR product of expected size. (E) Autoradiograph of PCR reaction products fractionated on $6 \%$ polyacrylamide ureapolyacrylamide gel. Samples were identical to D.

reaction (Fig. 3C, lane 3). Third, diffuse bands of $\sim 1,2$, and 3 RNA molecules in length appeared, confirming that the RNA ligase was able to ligate the RNA molecules (Fig. 3C, lane 3). Fourth, the diffuse bands all migrated more slowly than predicted by the sum of their RNA lengths, suggesting that each monomer, dimer, or trimer of RNA had a variable number of 12-nucleotide BamHI linkers ligated at each end. Thus, the RNA ligase reaction successfully coupled the ssDNA $B a m \mathrm{HI}$ linkers to the RNA, and there were on average $\sim$ three to five linkers per RNA end.

To the heat-inactivated ligation reactions were added 250 pmoles of additional BamHI linker (partially labeled, $100,000 \mathrm{cpm}$ per reaction, boiled and quenched on ice prior to addition) and other components required for reverse transcription. After incubation, the firststrand cDNA mixtures were immediately used for PCR amplification.

Because the 12-nucleotide BamHI linkers had a predicted ${ }^{(15)} T_{m}=44^{\circ} \mathrm{C}$, a low temperature was used for primer annealing and primary extension, followed by a higher temperature for secondary extension. All thermal ramps were as rapid as possible. PCR consisted of $35 \mathrm{cy}-$ cles of $95^{\circ} \mathrm{C}$ for $30 \mathrm{sec}, 37^{\circ} \mathrm{C}$ for $60 \mathrm{sec}$ to allow primer annealing and primary extension, $72^{\circ} \mathrm{C}$ for $30 \mathrm{sec}$ for complete extension. The final $72^{\circ} \mathrm{C}$ step was for 15 min to maximize full-length product formation. The PCR products were extracted with phenol/chloroform, ethanol precipitated, and resuspended in TE. Half of each PCR product was digested with BamHI.

When run on an ethidium bromidestained agarose gel, no detectable product was observed in the reaction with linkers alone (Fig. 3D, lanes 2,3). Thus, despite using short, palindromic, $100 \%$ complementary primers, there was little or no primer-dimer or other PCR artifacts. In the reaction with linkers and RNA, a discrete band of the expected size was observed, some slight size heterogeneity was apparent, and no other discrete bands were observed (Fig. 3D, lane 4 ). When digested with BamHI, the position and intensity of the ethidium bromide-stained band was not significantly changed (Fig. 3D, lane 5).

Similar results were obtained when the samples were fractionated on a native $6 \%$ polyacrylamide gel and analyzed by autoradiography (Fig. 3E). In addition, because most of the label in the PCR products was incorporated in the $5^{\prime}$ phosphate of the PCR primers, it was possible to analyze the nature of the ends and the completeness of the BamHI digestion. As expected, the majority of the label in the PCR product was removed by Bam HI digestion (Fig. 3E, lane 5), even though ethidium bromide staining revealed that the bulk of the DNA was resistant to BamHI digestion (Fig. 3D, lane 5). Thus, it was clear that the cDNA synthesis and PCR amplification were successful, that the product did not contain an internal BamHI site, and that the BamHI linkers were successfully cleaved in preparation for cloning.

\section{Analysis of cDNA Clones}

The BamHI-digested PCR product was gel-purified and cloned into the BamHI site of the pBluescript II KS + cloning vector (Stratagene). Transformants with inactivated $\beta$-galactosidase function were picked, and their plasmid cDNA insert sizes were determined by PCR analysis using the T3 and T7 primers. As shown in Figure 4A, all putative clones contained inserts, and the insert sizes were heterogeneous and within the expected size range. The size heterogeneity suggested that there were multiple, independent cDNA PCR products.

Ten cDNA clones were chosen, and both strands of each were sequenced. A summary of the cDNA sequence information is shown in Figure 4B. Three of the clones had exact sequence matches with each other and with a segment of the $S$. pombe $25 S$ rRNA gene, but they had heterogeneous endpoints. They were therefore multiple, independent isolates of the same or closely related fragments of $25 \mathrm{~S}$ rRNA present in the 210-nucleotide RNA band. One cDNA clone with an exact sequence match with part of $E$. coli insertion sequence IS5 presumably arose from a contaminant of one of enzymes derived from $E$. coli used in the cloning strategy. Similarly, another insert had homology to $126 \mathrm{bp}$ of insertion sequence IS406, presumably also a contaminant. The remaining five cDNA clones were independent clones that shared no significant homology with each other or with any sequence present in the GenBank and EMBL DNA data bases. These clones either were contaminants (like the IS5 and IS406 clones) or were derived from independent, heterogeneous RNA molecules associated with the Mts1/Mts2 protein.

\section{DISCUSSION}

We have purified to near homogeneity a 


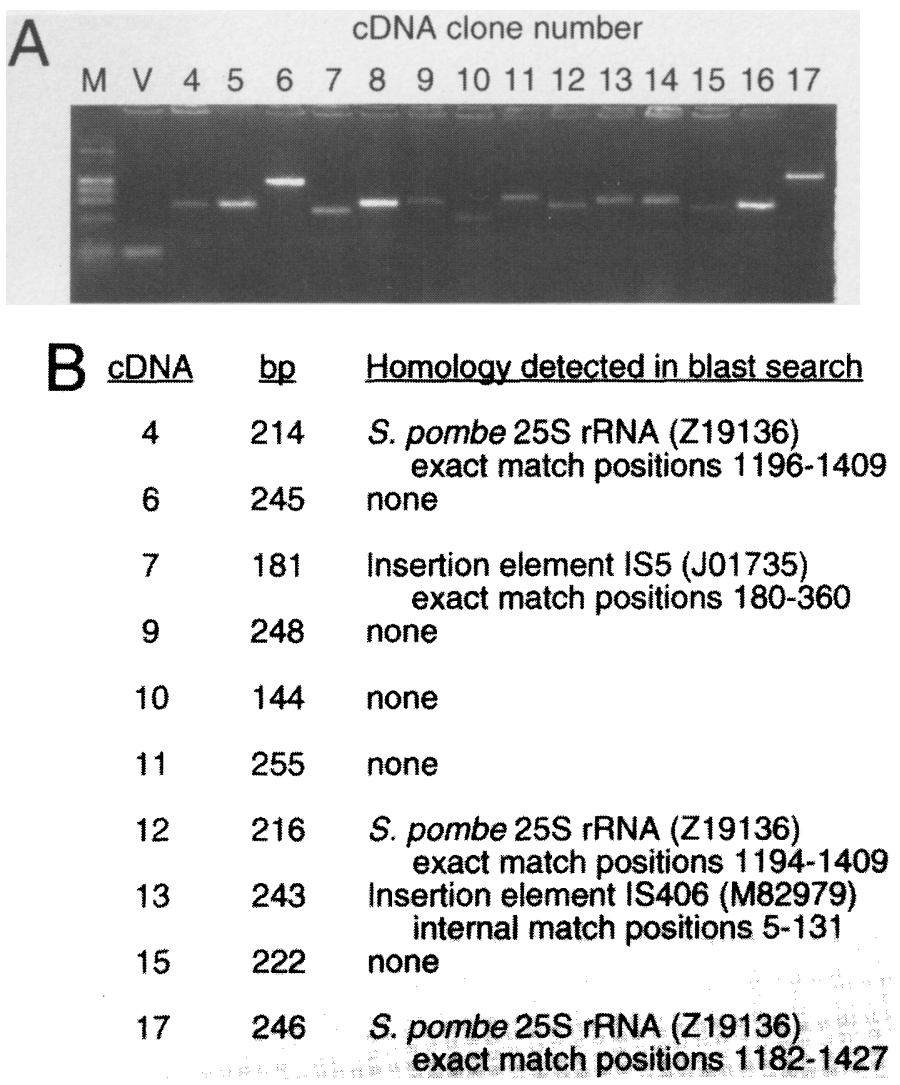

FIGURE 4 Analysis of cDNA clones. (A) Ethidium bromide-stained, 3\% agarose gel analysis of cDNA clone inserts amplified by PCR. The amplified fragment contains $164 \mathrm{bp}$ of vector between the T3 and T7 primers plus the cDNA insert. (Lane $M$ ) $\phi X 174$ HaeIII markers; (lane $V$ ) vector alone; (lanes 4-17) cDNA clones. (B) Sequence analysis of cDNA clones. Homologies detected by a Blast search of DNA data bases at the National Center for Biotechnology Information are shown.

heterodimeric protein, composed of polypeptide subunits Mts1 (70 kD) and Mts2 (28 kD) (Fig. 3A), that activates the ade6-M26 meiotic homologous recombination hot spot in $S$. pombe. ${ }^{(4)}$ In that study we showed that although the Mts1/Mts2 heterodimer alone was competent for DNA binding, a third factor seemed to be associated with the heterodimer. No good polypeptide candidate for that third factor was identified, leading us to test the hypothesis that the third factor was nucleic acid.

Although it is evident that RNA molecules of $\sim 210$ nucleotides in length (Fig. 1) are present in the purest protein preparations (Fig. 3A), it must be stressed that there is no direct evidence that those RNA molecules constitute a functional subunit of the recombination hot spot activating protein. It is clear, however, that the RNA molecules must be tightly associated with the Mts1/Mts2 protein; five separate steps in the protein purification each would have fraction- ated free nucleic acids away from the Mts1/Mts2 heterodimer. ${ }^{(4)}$

To confirm or exclude a biological role for these or any other protein-associated RNAs, it is necessary to disrupt their genes and examine the resulting phenotypes. A prerequisite was the development of a means to clone lowabundance, partially degraded RNA molecules of unknown sequence composition.

Demonstrated here is the utility of a simple and efficient means of cloning low-abundance, unknown RNA molecules. Because the RNA sequence was unknown, RNA ligase was used to add short pieces of DNA, 12-nucleotide BamHI linkers, to the ends of the RNA to serve as priming sites for both reverse transcription and PCR. This procedure could also be used to ligate the linkers onto unknown ssDNA for direct PCR amplification. To clone unknown dsDNA one could either boil the substrate prior to ligation, or use DNA ligase to ligate an- nealed BamHI linkers to the ends of the dsDNA. In the latter case, it would be necessary to insure that the dsDNA was blunt-ended prior to the linker addition.

One general rule for successful PCR is that the primers should be long enough to have a $T_{m}$ of $55-80^{\circ} \mathrm{C}$ and they should have approximately a $50-60 \% \mathrm{G}: \mathrm{C}$ content. ${ }^{(15)}$ These criteria reduce the likelihood of spurious primer annealing and artifactual PCR product formation. That rule was broken: 12-nucleotide, commercially available Bam HI linkers with a $T_{m}$ of $44^{\circ} \mathrm{C}$ were used as the primers. Despite their short length, low melting temperature, and an 83\% G:C content, no spurious amplification products were observed in either the control or experimental reactions (Figs. 3D,E).

A second general rule for successful PCR is that the primers should not be palindromic. ${ }^{(15)}$ This is to prevent hairpin formation that could lead to spurious priming or could block the annealing of primers to template. For the sake of simplicity, that rule was also broken: $100 \%$ palindromic BamHI linkers were chosen so that the same molecules could provide both the priming sites and the primers. This strategy worked, presumably because the hairpin $T_{m}$ was $22^{\circ} \mathrm{C}$, the annealing temperature was $37^{\circ} \mathrm{C}$, and the nonhairpin primer $T_{m}$ was $44^{\circ} \mathrm{C}$. This suggests that any $100 \%$ palindromic oligonucleotide could be used for this strategy as long as the primer annealing temperature used is between the hairpin melting temperature and the nonhairpin melting temperature. One could, for example, use longer palindromic linkers that contain several different restriction sites. Thus, if the PCR cDNA product contained one of those restriction enzyme sites internally, one of the other restriction sites could be used for cloning.

A third general rule for successful PCR is to use noncomplementary primer pairs, because primer-primer annealing could compete substantially with primer-template annealing. ${ }^{(15)}$ That rule was broken by using primers that were $100 \%$ complementary. Although some competition may have occurred, sufficient product was formed to allow each reaction to be analyzed several times on ethidium bromide-stained gels (Fig. 3D, lanes 4,5 ) and to provide material for cloning.

Of the $10 \mathrm{cDNA}$ clones that were sequenced, 5 matched known sequences 
in DNA sequence data bases. Because three of those clones were from nearly identical fragments of $25 S$ rRNA from $S$. pombe, differing only by their endpoint positions, the cloning strategy was judged to be successful; multiple independent isolates of the same sequence were obtained. The discrete 210-nucleotides RNA band associated with the Mts1/Mts2 protein is therefore partially composed of this small 25S rRNA fragment. The cloning of IS5 and IS406 elements from $E$. coli, however, urges caution. Presumably, these elements entered the amplification as contaminants of one of the enzymes used or from contamination during manipulation of samples. Thus, as with all PCR strategies, fastidiousness and cleanliness are requisites for success.

Although the 210-nucleotide RNA molecules were initially candidates for the third subunit of the recombination hot spot activating protein, this seems unlikely. In addition to the three $25 \mathrm{~S}$ rRNA fragments, five independent novel clones were also obtained. Thus, it seems that a heterogenous collection of small RNA molecules copurified 40,000-fold with the Mts1/Mts2 protein. Furthermore, a number of other experiments (such as analyzing the effect of treating the protein with RNase and assaying M26 DNA-binding activity) have failed to demonstrate a necessary role for the RNA in the protein's interaction with the M26 site. ${ }^{(16)}$ Another $S$. pombe DNAbinding protein that was purified 600fold using similar procedures ${ }^{(17)}$ did not contain any detectable nucleic acid. ${ }^{(18)}$ It is inferred that there were tight but nonspecific binding interactions between the Mts1/Mts2 heterodimer and fragmented RNA molecules present at the initial steps of protein purification. Because rRNA is abundant in cells, it is not surprising that $30 \%$ of the clones were derived from $25 S$ rRNA.

In conclusion, a PCR-based strategy was developed to enable cloning of unknown RNA molecules that were found associated with the Mts1/Mts2 heterodimeric recombination hot spot activating protein. This cloning strategy could be applied to the cloning of any unknown RNA (or DNA) molecules.

\section{ACKNOWLEDGMENTS}

I am grateful to Sue Amundsen for advice on the analysis of protein-associated
RNA molecules. Computer analyses were made possible by the National Center for Biotechnology Information and by a National Cancer Institute grant (NCI P30 CA15704-20) to the Fred Hutchinson Biocomputing Resource Center. This work was supported by a grant from the U.S. Public Health Service (GM31693 to Gerald R. Smith) and by a Damon Runyon-Walter Winchell Postdoctoral Fellowship (DRG1110).

\section{REFERENCES}

1. Wahls, W.P. and G.R. Smith. 1993. The M26 homologous recombination hotspot: Sequences, factors, and chromosomal context. In Chromosomes today (ed. A.T. Sumner and A.R. Chandley), vol. 11, pp. 351-363. Chapman \& Hall, London, UK.

2. Gutz, H. 1971. Site specific induction of gene conversion in Schizosaccharomyces pombe. Genetics 69: 317-337.

3. Schuchert, P., M. Langsford, E. Kaslin, and J. Kohli. 1991. A specific DNA sequence is required for high frequency of recombination in the ade6 gene of fission yeast. $E M B O J$. 10: 2157-2163.

4. Wahls, W.P. and G.R. Smith. 1993. A heterodimeric protein that activates a meiotic homologous recombination hotspot. (in prep.).

5. Kole, R. and S. Altman. 1981. Properties of purified ribonuclease $P$ from Escherichia coli. Biochemistry 20: 1902-1906.

6. Reed, R.E., M.F. Baer, C. Guerrier-Takada, H. Donis-Keller, and S. Altman. 1982. Nucleotide sequence of the gene encoding the RNA subunit (M1 RNA) of ribonuclease P of Escherichia coli. Cell 30: 627637.

7. Greider, C.W. and E.H. Blackburn. 1987. The telomere terminal transferase of Tetrahymena is a ribonucleoprotein enzyme with two kinds of primer specificity. Cell 51: 887-898.

8. Greider, C.W. and E.H. Blackburn. 1989. A telomeric sequence in the RNA of Tetrahymena telomerase required for telomere repeat synthesis. Nature 337: 331-337.

9. Young, L.S., H.M. Dunstan, P.R. Witte, T.P. Smith, S. Ottonello, and K.U. Sprague. 1991. A class III transcription factor composed of RNA. Science 252: 542-546.

10. Amundsen, $\mathrm{S}$. (pers. comm.).

11. Laemmli, U.K. 1970. Cleavage of structural proteins during the assembly of the head of bacteriophage T4. Nature 227: 680-685.

12. Gallagher, S.R. and J.A. Smith. 1989. Electrophoretic separation of proteins. In Current protocols in molecular biology (ed. F.M. Ausubel, R. Brent, R.E. Kingston, D.D. Moore, J.G. Seidman, J.A. Smith, and K.
Struhl), pp. 10.2.1-10.2.17. John Wiley, New York.

13. Maniatis, T., E.F. Fritsch, and J. Sambrook. 1982. Molecular cloning: A laboratory manual. Cold Spring Harbor Laboratory, Cold Spring Harbor, New York.

14. Devereux, J., P. Haeberli, and O. Smithies. 1984. A comprehensive set of sequence analysis programs for the VAX. Nucleic Acids Res. 12: 387-395.

15. Gelfand, D.H. and M.A. Innis. 1990. Optimization of PCRs. In PCR protocols: $A$ guide to methods and applications (ed. M.A. Innis, D.H. Gelfand, and T.J. White), pp. 3-12. Academic Press, San Diego, CA.

16. Wahls, W.P. (unpubl.).

17. Wahls, W.P. and G.R. Smith. 1993. Singlestranded DNA binding activity of $\mathrm{C}_{1}$-tetrahydrofolate synthase enzymes. J. Biol. Chem. 268: 23792-23798.

18. Wahls, W.P. and G.R. Smith (unpubl.).

Received October 12, 1993; accepted in revised form February 14, 1994. 


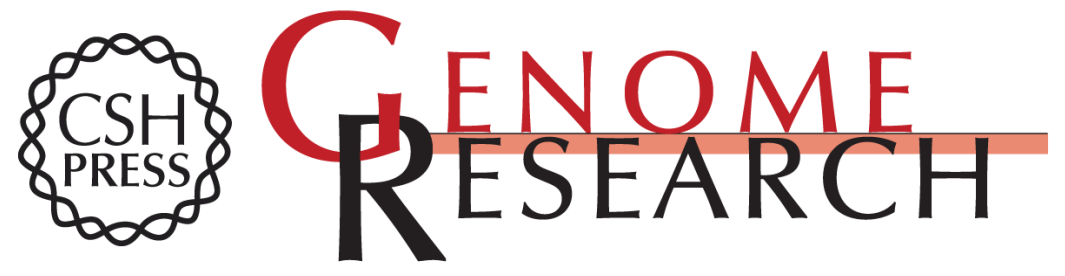

\section{RNA associated with a heterodimeric protein that activates a meiotic homologous recombination hot spot: RL/RT/PCR strategy for cloning any unknown RNA or DNA.}

W P Wahls

Genome Res. 1994 3: 272-277

References This article cites 10 articles, 3 of which can be accessed free at:

http://genome.cshlp.org/content/3/5/272.full.html\#ref-list-1

\section{License}

Email Alerting

Service

Receive free email alerts when new articles cite this article - sign up in the box at the top right corner of the article or click here.

\section{Affordable, Accurate Sequencing.}

